\title{
ANALISIS PENGETAHUAN PENGETAHUAN PERAWAT DALAM MEMBERIKAN DIAGNOSA KEPERAWATAN
}

\author{
FLORENCE ANGELINE NAINGGOLAN
}

florenceangeline123@gmail.com

\section{LatarBelakang}

Menurut Nursalam (2012) ,Perawat professional dalam memberikan pelayanan keperawatan di masa depan adalah harus berkomunikasi secara lengkap,adekuat dan cepat.

Proses keperawatan merupakan metode ilmiah yang dipakai dalam memberikan asuhan keperawatan yang professional.

Perawat, dimana saja ia bertugas,mengahadapi klie dengan segala macam kasus, dan melayani klien pada semua tingkat usia juga harus menggunakan proses keperawatan.

Perawat diharapkan memahami tentang konsep proses keperawatan dan mampu menerapkan serta menyusunkan dalam sebuah dokumen status kesehatan klien (Rohmah, N dan Adam Walid, S. 2009)

Asuhan Profesional dituntuk untuk dapat melaksanakan proses keperawatan dengan tepat dan benar . Pemahaman mahasiswa terhadap proses keperawatan sangat penting.

Karena topic ini akan menjadi bagian yang amat penting,karena topik ini akan menjadi bagian yang amat penting dalam pelaksanaan asuhan keperawatan.

Perbedaan asuhan yang professional dengan asuhan tradisional terletak pada penggunaan proses keperawataan.

Kenampuan perawat dalam menerapkan proses keperawatan dalam asuhannya sudah tidak dapat ditawar lagi apabila ia meyakini bahwa asuhannya adalah asuhan yang professional ( Rohmah, $\mathrm{N}$ dan Walid, S, 2009).

Pelayanan keperawatan professional merupakan bagian integral dari pelayanan kesehatan, dilaksanakan berdasarkan ilmu dan kiat keperawatan melalui asuhan keperawatan meliputi aspek biologis,psikologis, sosial dan spiritual.

Perawat memandang manusia sebagai makhluk yang berespon holistik terhadap perubahan kesehatan atau keadaan krisis.

Pemberian asuhan keperawatan yang komprehensif memberikan manfaat yang sangat besar bagi kesembuhan pasien, karena kondisi kesehatan fisik pasien seringkali dipengaruhi oleh kondisi jiwa dan spiritualnya (Arozullah, Padela, Volkan Stodolsky, \& Kholwadia, 2018), oleh karena itu asuhan keperawatan kompeherensif diberikan oleh perawat kepada pasien tidak bisa terlepas dari aspek spiritual. 
Implementasi asuhan keperawatan spiritual di rumah sakit, seharusnya dilakukan secara utuh, yaitu mengikuti alur proses keperawatan mulai pengkajian spiritual, penentuan diagnosis keperawatan spiritual, membuat perencanaan, implementasi dan evaluasi (Inggriane, 2017),

\section{Metode}

Diagnosa keperawatan melalui pemahaman yang diambil dari Jurnal, text book, dan artikelartikel terpecaya yang memiliki keterkaitan dengan sejarah keperawatan dan proses keperawatan. Hasil : dapat digunakan sebagai acuan untuk menentukan diagnosa keperawatan. Rancangan dalam penelitian ini menggunakan jenis penelitian kualitatif, yang bertujuan untuk mendapatkan gambaran secara mendalam tentang pelaksanaan sasaran keselamatan pasien.

\section{Hasil}

Rumah Sakit (RS) adalah institusi pelayanan kesehatan bagi masyarakat dengan karateristik tersendiri yang dipengaruhi oleh perkembangan ilmu pengetahuan kesehatan, kemajuan teknologi, dan kehidupan sosial ekonomi masyarakat yang harus tetap mampu meningkatkan pelayanan yang lebih bermutu dan terjangkau oleh masyarakat agar terwujud derajat kesehatan yang setinggi- tingginya, seperti yang dijelaskan dalam UndangUndang Kesehatan Nomor 36 Tahun 2009 dan Undang-Undang Rumah Sakit Nomor 44 Tahun 2009 bahwa rumah sakit wajib melaksanakan pelayanan kesehatan yang aman, bermutu, anti diskriminasi dan efektif, dengan mengutamakan kepentingan pasien. Rumah sakit wajib memenuhi hak pasien memperoleh keamanan dan keselamatan selama dalam perawatan di rumah sakit.

(Permenkes RI Nomor 1961/Menkes/2011). Keselamatan Pasien (patient safety) merupakan isu global dan nasional bagi rumah sakit, komponen penting dari mutu layanan kesehatan, prinsip dasar dari pelayanan pasien dan komponen kritis dari manajemen mutu (WHO, 2014). Ada lima isu penting yang terkait dengan keselamatan (safety) di rumah sakit yaitu: keselamatan pasien (patient safety), keselamatan pekerja atau petugas kesehatan, keselamatan bangunan dan peralatan di rumah sakit, keselamatan lingkungan (green productivity) dan keselamatan bisnis rumah sakit. Ke lima aspek keselamatan tersebut sangatlah penting untuk dilaksanakan di setiap rumah sakit. Harus diakui kegiatan institusi rumah sakit dapat berjalan apabila ada pasien. Karena itu keselamatan pasien merupakan prioritas utama untuk dilaksanakan dan hal tersebut terkait dengan isu mutu dan citra perumahsakitan (Depkes, 2015, p.17) 


\section{Pembahasan}

Proses keperawatan adalah aktivitas yang mempunyai maksud yaitu praktik keperawatan yang dilakukan dengan cara yang sistematik. Selama melaksanakan proses keperawatan, perawat menggunakan dasar pengetahuan yang komprehensif untuk mengkaji status kesehatan klien, membuat penilaian yang bijaksana dan mendiagnosa, mengidentifikasi hasil akhir kesehatan klien dan merencanakan, menerapkan dan mengevaluasi tindakan keperawatan yang tepat guna mencapai hasil akhir tersebut (Dermawan, 2012).

Perawat seseorang yang memiliki asuhan keperawatan dan harus memiliki proses keperawatan yang baik dan benar,untuk melakukan proses keperawatan ada lima tahap yang harus dilakukan,yang pertama yaitu tahap pengkajian,dimana merupakan tahap awal proses keperawatan dan merupakan suatu proses yang sitematis dalam pengumpulan data dari berbagai sumber data untuk mengevaluasi dan mengidentifikasi status kesehatan klien. Pengkajian yang lengkap ,akurat ,sesuai,kenyataan, kebenaran,data sangat penting untuk merumuskan suatu diagnose keperaewatan dan dalam memberikan asuhan keperawatan sesuai dengan respon individu.

Ada dua pengumpulan data yang pertama data dasar,dimana data dasar adalah kumpulan data yang berisikan mengenai status kesehatan klien, kemampuan klien untuk mengelola kesehatan terhadap diri nya sendiri,dan hasil konsultasi dari medis atau profesi kesehatan lainnya,yang kedua yaitu data focus dimana merupakan data tentang perubahan-perubahan atau respons klien terhadap kesehatan dan masalah kesehatan nya serta hal-hal yang mencakup tindakan yang dilaksanakan terhadap klien. Yang kedua diagnosa keperawatan dimana kenyataan yang menguraikan respons actual atau potensial klien terhadap masalah kesehatan yang perawat mempunyai izin dan berkompeten untuk mengatasinya.

Respon actual potensial klien di dapatkan dari dasar-dasar pengkajian,tinjauan literature yang berkaitan ,catatan medis klien masa lalu,dan konsultasi dengan professional lain.yang ketiga yaitu tahap perencanaan,dimana memberikan kesempatan kepada perawat ,klien, keluarga, dan orang terdekat klien untuk merumuskan rencana tndakan keperawatan guna mengatasi masalah yang dialami klien.

Intervensi keperawatan harus spesifik dan dinyatakan denganjelas. Pengkualifikasian seperti bagaimana, kapan, dimana, frekuensi, dan besarnya memberikan isi dari aktivitas yang direncanakan. Yang ke empat yaitu implementasi merupakan komponen dari proses keperawatan adalah kategori dari perilaku keperawatan dimana tindakan yang diperlukan untuk menacapai tujuan dan hasil yang diperkirakan dari asuhan keperawatan yang diselesaikan. Adapun kegiatan yang didalam tahap implementasi yaitu: pengkajian ulang, memperbaharui data dasar, meninjaun merevisi rencana asuhan yang telah dibuat dan melaksanan intervensi keperawatan yang telah direncanakan. 
Tahap yang terakhir yaitu evaluasi,evaluasi adalah tahap proses kepeawatan yang merupakan peerbandingan yang sistematis dan terencana antara hasil akhir yang teramati dan tujuan atau kriteria hasil yang dibuat pada tahap perencanaan.jika hasil evaluasi menunjukkan tercapainya tujuan dan kriteria hasil, klien bisa keluar dari siklus proses keperawatan.

Proses evaluasi memerlukan beberapa keterampilan dalam menetapkan rencana asuhan keperawatan, termasuk pengetahuan mengenai standar asuhan keperawatan, dan memiliki respon klien yang normal terhadap tindakan keperawatan, dan pengetahuan konsep teladan dari keperawatan

Untuk menjadi seseorang perawat harus melaksanakan proses keperawatan yang baik dan benar. Tidak hanya baik dan benar,tetapi perawat mampu memliki satu pendekatann untuk pemecahan masalah yang memampukan perawat untuk mengatur seseuatu asuhan keperawatan kepada klien. Pendekatan keperawatan memungkinkan perawat untuk mengidentifikasikan seluruh kebutuhan yang diperlukan klien.

Proses menjalankan tugas sebagai pemberi asuhan keperawatan, perawat berwenang untuk menegakkan diagnosis keperawatan (Pasal 30 UU No.38 tahun 2014).

Kegiatan analisis data dalam perumusan diagnosa keperawatan merupakan kemampuan kognitif dalam pengembangan daya berfikir dan penalaran yang dipengaruhi oleh latar belakang ilmu dan pengetahuan yang dimiliki seorang perawat.

Analisis data dalam perumusan diagnosa keperawatan dimulai dengan pengelompokan data yang diperoleh dari anamnesa, pengamatan dan pemeriksaan fisik lalu hasil yang didapat dibandingkan dengan standar (kondisi normal), sehingga dapat diketahui permasalahan kesehatan yang dialami pasien dan dapat dirumuskan masalah kesehatan.

Saat melakukan analisis data untuk perumusan diagnosa keperawatan kemampuan seorang perawat sangat diperlukan untuk mengkaitkan data dan menghubungkan data tersebut dengan konsep teori sehingga perawat mampu merumuskan diagnosa keperawatan dengan tepat (Dermawan, 2012).

Dalam memberikan diagnosa keperawatan, penting adanya pengetahuan dari perawat. Perawat adalah seorang profesional yang mempunyai kemampuan, tanggung jawab dan kewenangan melaksanakan pelayanan asuhan keperawatan pada berbagai jenjang pelayanan keperawatan. Pemenuhan kebutuhan kepuasan pasien selama di rumah sakit diperlukan tenaga kesehatan yang harus mempunyai pengetahuan (knowledge), keterampilan (skill) yang tinggi serta mempunyai sikap profesional (attitude) dan dapat menunjang pembangunan kesehatan. Pelayanan yang diberikan akan berkualitas dan dapat memberikan kepuasan pada pasien sebagai penerima pelayanan maupun perawat sebagai pemberi pelayanan (Hamid,2000). Karakteristik dari perawat terdiri dari kemampuan dan ketrampilan fisik dan mental dari individu sebagai perawat. Karakteristik ini dipengaruhi juga oleh latar belakang keluarga, tingkat sosial, pengalaman, umur, jenis kelamin, dan etnis. Perawat sebagai pekerja memiliki karakteristik individu yang berpengaruh terhadap hasil manajemen. 
Diagnosa keperawatan adalah suatu kesimpulan yang dihasilkan dari analisa data (Carpenito, 2009). Diagnosa keperawatan adalah langkah kedua dari proses keperawatan yang menggambarkan penilaian klinis tentang respon individu, keluarga, kelompok maupun masyarakat terhadap permasalahan kesehatan baik aktual maupun potensial. Dimana perawat mempunyai lisensi dan kompetensi untuk mengtasinya ( Sumijatun, 2010 ). Komponen diagnosa keperawatan menurut PPNI (2010) terdiri dari masalah (P), etiologi atau penyebab $(\mathrm{E})$ dan tanda atau gejala $(\mathrm{S})$ atau terdiri dari masalah dengan penyebab $(\mathrm{PE})$.

Proses Keperawatan Merupakan suatu metode yang sitematis dan terorganisasi dalam pemberian asuhan keperawatan, yang difokuskan pada reaksi dan respons untuk individu pada suatu kelompok atau perorangan terhadap gangguan kesehatan yang dialami, baik aktual maupun potensial. Proses keperawatan juga dapat diartikan sebagai pendekatan yang digunakan perawat dalam memberikan asuhan keperawatan, sehingga kebutuhan dasar klien dapat terpenuhi. Salah satu manfaat dari penerapan proses keperawatan yang baik adalah meningkatkan mutu dan kualitas pelayanan dalam bidang keperawatan Asuhan keperawatan dikatakan baik apabila perawat sudah melaksanakan tahap tahap dalam memberikan asuhan keperawatan kepada pasien yaitu tahap pengkajian, diagnosa, perencanaan, implementasi dan Evaluasi.

\section{Penutup}

Diagnosis Keperawatan merupakan keputusan klinik tentang respon individu, keluarga dan masyarakat tentang masalah kesehatan aktual atau potensial, dimana berdasarkan pendidikan dan pengalamannya, perawat secara akontabilitas dapat mengidentifikasi dan memberikan intervensi secara pasti untuk menjaga, menurunkan, membatasi, mencegah dan merubah status kesehatan klien .

Diagnosis keperawatan ditetapkan berdasarkan analisis dan interpretasi data yang diperoleh dari pengkajian keperawatan klien. Diagnosis keperawatan memberikan gambaran tentang masalah atau status kesehatan klien yang nyata (aktual)

Diagnosis keperawatan telah diterapkan di berbagai rumah sakit dan fasilitas kesehatan lainnya, namun pengetahuan perawat terkait indikator-indikator diagnostik untuk penegakan diagnosis masih perlu ditingkatkan agar penegakan dapat dilakukan secara tepat dan terstandarisasi, serta proses penegakan diagnosisi tidak dianggap sulit. Tanpa terminologi dan indikator yang terstandarisasi, penegakan diagnosis keperawatan menjadi tidak seragam, tidak akurat sehingga menyebabkan ketidaktepatan pengambilan keputusan.

Tingkat Pengetahuan Perawat Pengetahuan adalah fakta, keadaan atau kondisi tentang pengertian mencakup kombinasi dari kesadaran sederhana tentang fakta dan pemahaman tentang bagaimana fakta itu berkaitan satu sama lain (Green,1980). Dalam kode etik keperawatan disebutkan bahwa 
perawat memiliki tanggung jawab agar senantiasa memelihara mutu pelayanan keperawatan yang tinggi disertai kejujuran profesional yang menerapkan pengetahuan serta ketrampilan keperawatan sesuai dengan kebutuhan klien. Dalam hubungannya dengan teman sejawat, perawat berkewajiban melindungi klien dari tenaga kesehatan yang memberikan pelayanan kesehatan secara tidak kompeten, tidak etis dan ilegal.

\section{Referensi}

Aprisunadi. (2017). Standar Diagnosis Keperawatan Indonesia. Jakarta: Dewan Penggurus Pusat Persatuan Perawat Nasional Indonesia.

Budiono, Sumirah B. P. (2015). Konsep dasar keperawatan. Jakarta: Bumi Medika. Dermawan, D. (2012). Proses keperawatan: Penerapan konsep \& kerangka kerja. Yogyakarta:Gosyen.

Cahyono, Agung. (2015). Hubungan Karakteristik dan Tingkat Pengetahuan Perawat terhadap Pengelolaan Keselamatan Pasien di Rumah Sakit. Jurnal Ilmiah WIDYA, 3(2), 97 - 102.

Donges, ME. 2010. Penerapan Proses Keperawatan dan Diagnosa Keperawatan. Jakarta : EGC Effendy, N. (2012). Pengantar Proses Keperawatan. Jakarta: EGC.

Fatie, Marselius, Zeth, Roberth, Felle. (2018). Hubungan Tingkat Pendidikan Perawat dengan Penerapan Kompetensi Pendokumentasian Proses Kepewatan. Jurnal Keperawatan Tropis Papua, $1(1)$.

Simamora, R. H., Bukit, E., Purba, J. M., \& Siahaan, J. (2017). Penguatan kinerja perawat dalam pemberian asuhan keperawatan melalui pelatihan ronde keperawatan di rumah sakit royal prima medan. Jurnal pengabdian kepada masyarakat, 23(2), 300-304.

Simamora, R. H. (2019). Socialization of Information Technology Utilization and Knowledge of Information System Effectiveness at Hospital Nurses in Medan, North Sumatra. Editorial Preface From the Desk of Managing Editor..., 10(9).

Stole, K.M. (2004). Diagnosa Keperawatan Sejahtera (E. Noviestari, Terj.). Jakarta: EGC (tulisan asli dipublikasikan tahun 1996).

Sumijatun.(2010). Konsep Dasar Menuju Keperawatan Profesional. Jakarta:TIM 
Susanto, R. (2010). Penerapan Standar Proses Keperawatan di Puskesmas Rawat Inap Cilacap. Jurnal Keperawatan Soedirman (The Soedirman Journal of Nursing), Vol.5,. No.

Wirdah, H. (2016). Penerapan Asuhan Keperawatan Oleh Perawat Pelaksana Di Rumah Sakit Banda Aceh. 1-6. 